\title{
An Examination of the Effects of Government Purchases in an Open Economy
}

\author{
Kent P. Kimbrough* \\ Department of Economics, Duke University, Durbam, NC 27706, USA
}

\begin{abstract}
This paper examines the effects of permanent and transitory changes in government purchases in the context of a model of a small open economy that produces and consumes both traded and nontraded goods. The model incorporates an equilibrium interpretation of the business cycle that emphasizes the responsiveness of agents to intertemporal relative price changes. It is demonstrated that transitory increases in government purchases lead to an appreciation of the real exchange rate and an ambiguous change (although a likely worsening) in the current account, while permanent increases have an ambiguous impact on the real exchange rate and no effect on the current account. When agents do not know whether a given increase in government purchases is permanent or transitory the effect is a weighted average of these separate effects. The weights depend on the relative variances of the transitory and permanent components of government purchases.
\end{abstract}

In the past few years a considerable amount of effort has been devoted to examining the effects of macroeconomic policy in an open economy. Such issues as exchange rate overshooting, deviations from purchasing power parity, sterilization and monetary control, the effectiveness of monetary policy, and the choice between alternative exchange rate regimes have been at center stage. The models that have been employed to study these issues have run the spectrum from variants of the Mundell-Fleming model such as Dornbusch (1976), Turnovsky (1981), and Kimbrough (1983a), to wage contracting and indexing models like Bhandari (1982b) and Flood and Marion (1982), to equilibrium models of the business cycle along the lines of Bhandari (1982a), Saidi (1982), and Kimbrough (1983b), to the closely related intertemporal utility maximization models with money of Helpman (1981) and Stockman $(1980,1983)$. One common thread that, in a sense, unifies all of these, and other, recent contributions is that they are concerned primarily with the effects of alternative monetary and exchange rate policies that the central bank might enact.

In light of the development and refinement during this period of the monetary approach to the balance of payments and the exchange rate, it is not surprising

*I would like to thank Phil Brock, Jeremy Greenwood, Gary Zarkin, and two anonymous referees for their helpful comments. 
that considerably less attention has been devoted to examining the role of fiscal policy. ${ }^{1}$ The purpose of this paper is to take a step towards closing this gap by examining the effects of fiscal policy in an open economy within the context of an equilibrium model. The paper focuses on the effects of government purchases, and extends to an open economy setting views outlined by Bailey (1971, esp. Ch. 9) and Barro (1981). Following Barro, a sharp distinction is made between the effects of permanent and transitory changes in government purchases. This distinction is necessary since only permanent changes in government purchases affect private sector wealth when agents properly account for the influence of government expenditure and financing decisions on their lifetime budget constraint. Government purchases are allowed to influence the private sector budget constraint directly through their impact on the present value of (net) tax payments as well as through the service flows they generate which substitute for private consumption, and through their influence on private productivity arising from the provision of public services.

The model used to discuss the effects of government purchases is one of a small open economy in which agents produce and consume traded and nontraded goods. Supply and demand on the part of the private sector depends on current period and intertemporal relative prices as well as on perceived wealth, where the latter depends on unperceived money growth, as in Barro (1980), and on the perceived level of permanent government purchases, as in Barro (1981). In addition, the private sector's demand for goods depends on the extent to which government purchases (permanent and transitory) substitute for, and hence crowd out, private consumption, while the private sector's supply of goods depends on the productivity effects of government purchases (permanent and transitory). The fiscal authorities are assumed to make decisions regarding toral (real) government purchases, its division into permanent and transitory components, and its allocation between purchases of traded and nontraded goods. Using this framework, particular attention is given to the influence of government purchases on real and nominal exchange rates, total domestic output and the output of nontraded goods, and the current account. The cases of full current information and incomplete information are both examined.

In the case of full current information two main results concern the effects of government purchases on the real exchange rate and the current account. It is shown that a transitory increase in government purchases will lead to an appreciation of the real exchange rate (i.e., a rise in the current period relative price of nontraded goods) and that this effect will, under plausible conditions, be stronger than that associated with a permanent increase in government purchases of the same magnitude. In addition, it is shown that a transitory increase in government purchases has an ambiguous impact on the current account while a permanent rise in government purchases will not affect the current account.

In the case of incomplete information it is demonstrated that agents will respond in the same manner to both permanent and transitory changes in government purchases in as much as they cannot accurately discriminate between the two. This implies that, relative to a full current information benchmark, agents will overrespond to permanent changes in government purchases (because wealth effects are underestimated) and underrespond to transitory changes in government purchases (because wealth effects are overestimated).

The paper is organized as follows: Section I outlines the model by discussing 
private sector behavior, the economy's links to the world cconomy, monetary and fiscal policy, and goods and asset market equilibrium conditions. Section II presents the model's solution under full current information and discusses the effects of permanent and transitory changes in government purchases. In addition changes in the nontraded-traded goods composition of government purchases are also briefly considered. The effects of government purchases under incomplete information are examined in Section III and shown to be a weighted average of the effects of permanent and transitory changes in government purchases under full current information. The fourth, and final, section briefly summarizes the paper's theoretical results and policy implications.

\section{The Model}

In order to discuss more fully the ideas and issues outlined in the introduction, this section presents an open economy extension of the intertemporal substitution model of Lucas and Rapping (1969). The model incorporates ideas advanced by Bailey (1971) and Barro $(1980,1981)$ and the reader is referred to these sources for a fuller treatment of the basic framework.

\section{A. Private Sector Bebavior}

Consider a small open economy with a flexible exchange rate that produces and consumes traded and nontraded goods. In addition, agents hold portfolios consisting of money and interest-bearing assets (bonds). Private agents maximize utility over their lifetimes and, in light of the information available to them, fully account for the impact of the government's fiscal operations. These fiscal operations affect private agents in four ways.

First, government purchases must be financed either by taxes (net of transfers) or by issuing interest-bearing government debt. ${ }^{2}$ Changes in the present value of the government purchase stream influence private agent's lifetime budget constraints via their impact on taxes, including those required to finance the government's debt. The timing of tax payments does not matter as private agents fully perceive the future tax liabilities associated with government debt. That is, the Ricardian-equivalence theorem is assumed to hold as in Barro (1974). In addition, changes in the timing of government purchases do not influence private wealth as long as they do not affect the present value of the government purchase stream.

Second, government purchases affect private sector behavior to the extent that the public services they provide substitute for private consumption. For instance, public provision of school lunches will lead parents to reduce their purchases of lunch foods for their children to the extent that school lunches are nutritionally equivalent to bag lunches from home. Thus government purchases crowd out private consumption, the extent of the crowding out depending on how well such purchases substitute for private consumption. In the present context, two crowding-out parameters are relevant. On the one hand the public services provided by government purchases may substitute for private consumption in general (both traded and nontraded goods) as measured by the parameter $\theta$, and on the other they may substitute for the private consumption of nontraded goods as measured by the parameter $\theta_{N}{ }^{3}$ At best the public services provided through 
government purchases are perfect substitutes for private consumption which implies that $0 \leqslant \theta, \theta_{N} \leqslant 1$.

The third channel through which government purchases influence the private sector is by enhancing or reducing private sector production opportunities through the provision of law enforcement, roads, and other elements of the infrastructure as well as through various regulations such as acreage restrictions and the rules laid down by regulatory bodies such as the FTC and OSHA. The impact of government purchases on productivity in the nontraded sector is captured by the parameter $\rho_{N}$ whilc their impact on the production possibilities facing the private sector in general is captured by the parameter $\rho$. Following Barro (1981) it is assumed that $\rho, \rho_{x} \leqslant 1$ which means that the net impact of government purchases on private production is less than the cost of providing the public services used as inputs.

Finally, government purchases are divided between traded and nontraded goods in the manner dictated by the fiscal authorities, with the fraction $\gamma_{N}$ of government purchases falling on nontraded goods. These purchases may influence relative prices in the economy and thereby influence private decisions regarding consumption and labor allocation. It should be noted at this point that the last three channels through which changes in government purchases may affect private sector behavior are operative regardless of whether or not the change represents a change in the present value of government purchases or just a change in their timing. Throughout the paper the former are referred to as permanent changes and the latter as transitory changes.

Formally, the private sector's behavior is described by equations $\langle 1\rangle-\langle 5\rangle$, The model's specification is based on the assumption that only changes in intertemporal relative prices (i.e., in the real interest rate) are associated with a reallocation of expenditure or labor effort between periods, and that given the levels of expenditure and labor effort allocated to any particular period their disposition between traded and nontraded goods is determined solely by withinperiod (intratemporal) relative prices. This specification is consistent with a utility function that is weakly homothetically separable in agent's consumption and leisure sequences, and for which the branch of the utility function associated with the consumption sequence is weakly homothetically separable across time periods. ${ }^{4}$ All variables are in levels except for the prices of traded and nontraded goods, $P_{\mathrm{Tt}}, P_{T t}^{*}$, and $P_{\mathrm{N} t}$, the exchange rate, $S_{t}$, and the domestic and foreign money supplies, $M_{t}$ and $M_{t}^{*}$-these variables are in logarithms.

$$
\begin{gathered}
y_{N t}=k_{N}^{s}+\eta_{N}^{s} p_{n t}+\alpha_{N}^{s} r_{t}-\beta_{N}^{s}\left[\left(m_{t}-E m_{t}\right)-(1-\theta-\rho) E G_{t}^{p}\right]+\rho_{N} G_{t}+u_{N t}^{s} \\
c_{N t}=k_{N}^{d}-\eta_{N}^{d} p_{n t}-\alpha_{N}^{d} r_{t}+\beta_{N}^{d}\left[\left(m_{t}-E m_{t}\right)-(1-\theta-\rho) E G_{t}^{P}\right]-\theta_{N} G_{t}+u_{N t}^{d} \\
y_{t}=k^{s}+\alpha^{s} r_{t}-\beta^{s}\left[\left(m_{t}-E m_{t}\right)-(1-\theta-\rho) E G_{t}^{P}\right]+\rho G_{t}+u_{t}^{s} \\
c_{t}=k^{d}-\alpha^{d} r_{t}+\beta^{d}\left[\left(m_{t}-E m_{t}\right)-(1-\theta-\rho) E G_{t}^{p}\right]-\theta G_{t}+u_{t}^{t} \\
M_{t}^{d}=P_{t}+\phi y_{t}-\lambda i_{t}+v_{t}
\end{gathered}
$$

Equations $\langle 1\rangle$ and $\langle 2\rangle$ give the private sector's supply of and demand for nontraded goods, $y_{N t}$ and $c_{N t}$. The supply of nontraded goods is positively related 
to their current period relative price, $p_{n t}=P_{N t}-P_{T t}$, and to the real rate of return, $r_{t}$. This latter influence captures the intertemporal substitution aspects of the model and reflects the fact that more labor will be supplied in periods where the real rate of return is high. The real rate of return is given by

$$
r_{t}=i_{t}-\left(E P_{s+1}-P_{t}\right)
$$

where $i_{t}$ is the domestic nominal interest rate and $P_{t}$ is the domestic price level which is given by

$$
P_{t}=\delta_{N} P_{N t}+\delta_{T} P_{T t} ; \delta_{N}+\delta_{T}=1,
$$

where $\delta_{j}$ is the share of expenditure falling on good $j$ and $E P_{t+1}$ is the price level agents expect to prevail in period $t+1$ conditional on the information available to them at time $t$. In addition, the supply of nontraded goods is negatively related to the private sector's perceived real wealth, $\left(m_{t}-E m_{t}\right)-(1-\theta-\rho) E G_{f}^{P}$, since leisure is assumed to be a normal good. The private sector's perceived real wealth has two distinct components. ${ }^{5}$ First, it depends on unperceived changes in the money growth rate as captured by the term $m_{t}-E m_{t}$, where $m_{t}$ is the actual money growth rate and $E m$, its perceived value. This component of private wealth is discussed by Barro (1980). Second, private wealth depends on the perceived level of permanent government purchases, $E G_{t}^{p}$, since (a) they imply a corresponding tax liability, (b) they generate a permanent consumption flow valued by private agents at the rate $\theta$, and (c) they permanently alter private production opportunities by the amount $\rho .^{6}$ These effects are captured by the term $-(1-\theta-\rho) E G_{t}^{P}$ which has been discussed by Barro (1981). Government purchases, both permanent and transitory, also directly affect productivity in the nontraded goods sector as shown by the term $\rho_{N} G_{r}$. In addition, random shocks influence nontraded goods supply as shown by $u_{N t}^{s}$ (mean zero, variance $\sigma_{N s}^{2}$ ). Similar interpretations apply to the demand for nontraded goods in equation $\langle 2\rangle$, where the term $-\theta_{N} G_{\text {, }}$ reflects the crowding out of private sector purchases of nontraded goods associated with government purchases, and the term $u_{N t}^{d}$ captures random influences on the private demand for nontraded goods (mean zero, variance $\sigma_{N d}^{2}$ ). In addition, to ease the exposition, it is assumed that $\theta_{N}=\gamma_{N} \theta$ and $\rho_{N}=\gamma_{N} \rho$. This directly ties the consumption and production effects of government purchases on the nontraded goods market to the volume of nontraded goods purchased by the government.

Equations $\langle 3\rangle$ and $\langle 4\rangle$ give domestic output (income) and private consumption (expenditure) $y_{t}$ and $c_{t}$, measured in terms of the price index $P_{t}$. Note that changes in current period relative prices, $p_{n t}$, do not affect real output since they occasion a reallocation of labor within the period rather than between periods and thus reflect a movement along a given production possibilities frontier. ${ }^{7}$ In contrast, changes in the real interest rate, $r_{t}$, do cause a reallocation of labor effort between periods (i.e., they shift the within period production possibilities frontier) and hence do influence contemporaneous real output. In addition to depending positively on the real interest rate, real output is negatively related to perceived real wealth since leisure is a normal good. Real output at time $t$ is also affected by the overall productivity effect associated with government purchases, $\rho G_{t}$, and by random elements $u_{t}^{\prime}$ (mean zero, variance $\sigma_{s}^{2}$ ). Again, the private sector consumption function, equation $\langle 4\rangle$, can be explained in a similar fashion. The term $-\theta G_{i}$ reflects the crowding out of private sector consumption 
by government purchases, while $u_{t}^{d}$ reflects random elements that affect agent's intertemporal consumption plans (mean zero, variance $\sigma_{d}^{2}$ ).

The final ingredient of the model that characterizes private sector behavior is the money demand function $\langle 5\rangle$. The (logarithm of the) private sector's demand for cash balances, $M_{t}^{d}$, depends on the price level, real income, and the nominal interest rate. ${ }^{8}$ There is also a money demand shock, $v_{i}$, with mean zero and variance $\sigma_{v}^{2}$ that enters the money demand function.

\section{B. Links with the World Economy}

The home country's links with the rest of the world reflect the channels through which goods and assets flow into and out of the country. It is assumed that domestic and foreign bonds are perfect substitutes so that the uncovered interest parity condition,

$$
i_{t}=i_{t}+\left(E S_{t+1}-S_{t}\right)
$$

holds at all times. In addition, arbitrage in the market for traded goods implies that

$$
P_{T t}=S_{t}+P_{T t}^{*}
$$

The behavior of world nominal interest rates and traded goods prices, $i_{i}^{*}$ and $P *$, are exogenous by virtue of the small country assumption. The structure of the world economy is similar to that of the home country, and following Bhandari (1982a) and Kimbrough (1983c) it can be shown that the behavior (of the stochastic elements) of world variables is governed by ${ }^{9}$

$$
\begin{gathered}
i_{t}=u_{t}^{d^{*}}+u_{t}^{*} \\
P_{T t}^{*}=M_{t-1}^{*}+m_{t}^{*}+\chi^{d} u_{t}^{d^{*}}+\chi^{s} u_{t}^{*},
\end{gathered}
$$

where $u_{t}^{* *}$ and $u_{t}^{i *}$ reflect world supply and demand shocks (zero means and variances $\sigma_{s^{*}}^{2}$ and $\sigma_{d^{*}}^{2}$ ) and the world money supply evolves according to

$$
M_{t}^{*}=M_{t-1}^{*}+m_{i}^{*} \text {. }
$$

\section{Monetary and Fiscal Policy}

The behavior of the domestic monetary and fiscal authorities is given by the following four equations:

$$
\begin{gathered}
M_{t}=M_{t-1}+m_{t} . \\
G_{t}=G_{t}^{P}+G_{t}^{T}, \\
G_{t}^{P}=G_{t-1}^{P}+e_{t}^{p} ; G_{t}^{T}=e_{t}^{T}, \\
G_{N t}=\gamma_{N} G_{t} .
\end{gathered}
$$

Equation 〈13 > describes the money supply rule adopted by the central bank; the rate of growth of the domestic money supply, $m_{t}$, has a variance of $\sigma_{m}^{2}$ about its mean rate of zero. ${ }^{10}$

The behavior of the country's fiscal authorities regarding the timing and allocation of (real) government purchases is described by equations $\langle 14\rangle-\langle 16\rangle$. 
Equation $\langle 14\rangle$ simply says that government purchases have both a permanent and a transitory component and equation $\langle 15\rangle$ describes the behavior of these components. The permanent component of government purchases, $G_{t}^{P}$, follows a random walk with innovation $e_{t}^{p}$ (mean zero, variance $\sigma_{p}^{2}$ ), while the transitory component, $G_{t}^{T}=e_{t}^{T}$, is purely random (with mean zero and variance $\sigma_{T}^{2}$ ). ${ }^{11}$ Equation $\langle 16\rangle$ indicates that the fraction $\gamma_{i N}$ of total government purchases falls on nontraded goods, whereas $G_{N_{t}}$ denotes government purchases of nontraded goods. ${ }^{12}$

\section{Market Clearing Conditions}

Equilibrium requires that the domestic markets for nontraded goods and money clear each period. That is, the market clearing conditions

$$
\begin{gathered}
y_{N t}=c_{N t}+G_{N t} \\
M_{t}=M_{t}^{d}
\end{gathered}
$$

must hold in every period. The behavior of the current account, $T_{t}$, is accordingly governed by the difference between domestic income and expenditure as given by ${ }^{13}$

$$
T_{t}=y_{t}-c_{t}-G_{t}
$$

\section{Government Purchases Under Full Current Information}

Unlike monetary policy, changes in government purchases may have real effects in equilibrium business cycle models even when they are fully perceived by private agents. The reason for this is that government purchases directly influence agents through their impact on agent's lifetime budget constraints, by substituting for private consumption, and by influencing the production possibilities frontier. In addition, government purchases also affect private sector decisions indirectly by altering relative prices, which they do to the extent that private and public expenditure patterns differ. For these reasons, the case where agents possess full current information is discussed in detail in this section. ${ }^{14}$

\section{A. Solution}

The model can be solved by applying the method of undetermined coefficients. Such a solution requires that expressions for two prices be obtained. Given the interest in relative prices, it is convenient to solve for the relative price of nontraded goods, $p_{m t}$, and the exchange rate, $S_{t}$. The postulated solutions are ${ }^{15}$

$$
\begin{gathered}
p_{n t}=\xi_{00}+\xi_{01} G_{t-1}^{P}+\xi_{02} M_{t-1}+\xi_{03} M_{t-1}^{*} \\
+\xi_{1} e_{t}^{p}+\xi_{2} e_{t}^{T}+\xi_{3} m_{t}+\xi_{4} u_{N t}+\xi_{5} u_{t}^{s}+\xi_{6} v_{t}+\xi_{7} u_{t}^{d^{*}}+\xi_{8} u_{t}^{*}+\xi_{9} m_{t}^{*}
\end{gathered}
$$

and

$$
\begin{gathered}
S_{t}=\pi_{00}+\pi_{01} G_{t-1}^{P}+\pi_{02} M_{t-1}+\pi_{03} M_{t-1}^{*} \\
+\pi_{1} e_{t}^{P}+\pi_{2} e_{t}^{T}+\pi_{3} m_{t}+\pi_{4} u_{N i}+\pi_{5} u_{t}^{t}+\pi_{6} v_{t}+\pi_{7} u_{t}^{d^{*}}+\pi_{8} u_{t}^{*}+\pi_{9} m_{t}^{*} .
\end{gathered}
$$


These postulated solutions, and the assumption of rational expectations, imply that

$\langle 22\rangle E p_{n t+1}=\xi_{00}+\xi_{01}\left(G_{t-1}^{p}+E e_{t}^{p}\right)+\xi_{02}\left(M_{t-1}+E m_{t}\right)+\xi_{03}\left(M_{t-1}^{*}+E m_{t}^{*}\right)$

$\langle 23\rangle S_{t+1}=\pi_{00}+\pi_{01}\left(G_{t-1}^{P}+E e_{t}^{P}\right)+\pi_{03}\left(M_{t-1}^{*}+E m_{t}\right)+\pi_{03}\left(M_{t-1}^{*}+E m_{t}^{*}\right)$,

where use has been made of $\langle 12\rangle,\langle 13\rangle,\langle 15\rangle$ and the properties of $e_{t}^{p}, m_{t}$, and $m_{t}^{*}$.

Expressions $\langle 20\rangle-\langle 23\rangle$ can be substituted into the model's semireduced form expressions for the equilibrium relative price of nontraded goods and the equilibrium exchange rate and, along with the assumption of full current information, the resulting expressions can be solved for the undetermined coefficients (the $\xi$ 's and the $\pi$ 's). With some straightforward but tedious manipulation, it can be shown that the semireduced form expressions required to solve the model are ${ }^{16}$

$$
\left(\eta_{N}+\alpha_{N} \delta_{N}\right) p_{n t_{-}}=k_{N}-\alpha_{N}\left[\left(1+\chi^{d}\right) u_{t}^{u^{*}}+\left(1+\chi^{s}\right) u_{t}^{s^{*}}+\left(m_{t}^{*}-E m_{t}^{*}\right)\right]+\alpha_{N} \delta_{N} E p_{n t+1}
$$

$$
+\beta_{N}\left[\left(m_{t}-E m_{t}\right)-(1-\theta-\rho) E G_{i}^{P}\right]+\gamma_{N}(1-\theta-\rho)\left(G_{i-1}^{P}-e_{i}^{P}+e_{i}^{T}\right)+u_{N t}
$$

and

$$
\begin{gathered}
(1+\lambda) S_{f}=M_{t-1}+\left(1+\phi \beta^{s}\right) m_{t}-\phi \beta^{s} E m_{t}-M_{t-1}^{*}-m_{t}^{*}-\phi \alpha^{s}\left(m_{t}^{*}-E m_{t}^{*}\right) \\
-\delta_{N}\left(1+\phi \alpha^{s}\right) p_{n t}+\phi \alpha^{s} \delta_{N} E p_{n t+1}-\phi k^{s}+\kappa^{d} u_{t}^{d^{*}}+\kappa^{s} u_{t}^{*}-\phi u_{t}^{s}-v_{t} \\
+\lambda E S_{t+1}-\phi \rho\left(G_{t-1}^{P}+e_{t}^{P}+e_{t}^{T}\right)+\phi \beta s(1-\theta-\rho) E G_{t}^{P}
\end{gathered}
$$

where $\eta_{N}=\eta_{N}^{d}+\eta_{N}^{s}, \quad \alpha_{N}=\alpha_{N}^{d}+\alpha_{N}^{s}, \quad \beta_{N}=\beta_{N}^{d}+\beta_{N}^{s}, k_{N}=k_{N}^{d}-k_{N}^{s}, u_{N}=u_{N t}^{d}-u_{N t}^{s}$ $\kappa^{s}=\lambda-\chi^{s}-\phi \alpha^{s}\left(1+\chi^{s}\right)$, and $\kappa^{d}=\lambda-\chi^{d}-\phi \alpha^{s}\left(1+\chi^{d}\right)$. The resulting solutions for the coefficients in $\langle 20\rangle$ and $\langle 21\rangle$ are presented in Table 1 . The 'tildes' denote that these are full current information solutions.

\section{B. Interpretation}

As a prerequisite for interpreting the solutions presented in Table 1 and their implications for the behavior of nominal and real variables, two issues need to be briefly touched on. The first concerns the interpretation of the excess demand elasticities appearing in equation $\langle 24\rangle$ and Table 1 , and the second concerns the government purchase coefficient $1-\theta-\rho$ appearing in equations $\langle 24\rangle$ and $\langle 25\rangle$ as well as in Table 1.

From equation $\langle 24\rangle$ it can be seen that $\eta_{N}+\alpha_{N} \delta_{N}$ is the excess demand elasticity for nontraded goods with respect to a change in their current period relative price, $p_{n r}$. It is also apparent from equation $\langle 24\rangle$ that $\alpha_{N} \delta_{N}$ is the excess demand elasticity for nontraded goods with respect to a change in their expected future relative price, $E p_{n t+1}$. Therefore, a change in the relative price of nontraded goods that agents perceive to be permanent (in which case $\left.\Delta p_{n t}=\Delta\left(E p_{n t+1}\right)\right)$ will alter the excess demand for nontraded goods by $\eta_{N}$, whereas a transitory change in their relative price (in which case $\Delta\left(E p_{n t+1}\right)=0$ ) alters excess demand by $\eta_{N}+\alpha_{N} \delta_{N}$. That is, a transitory change in the relative 


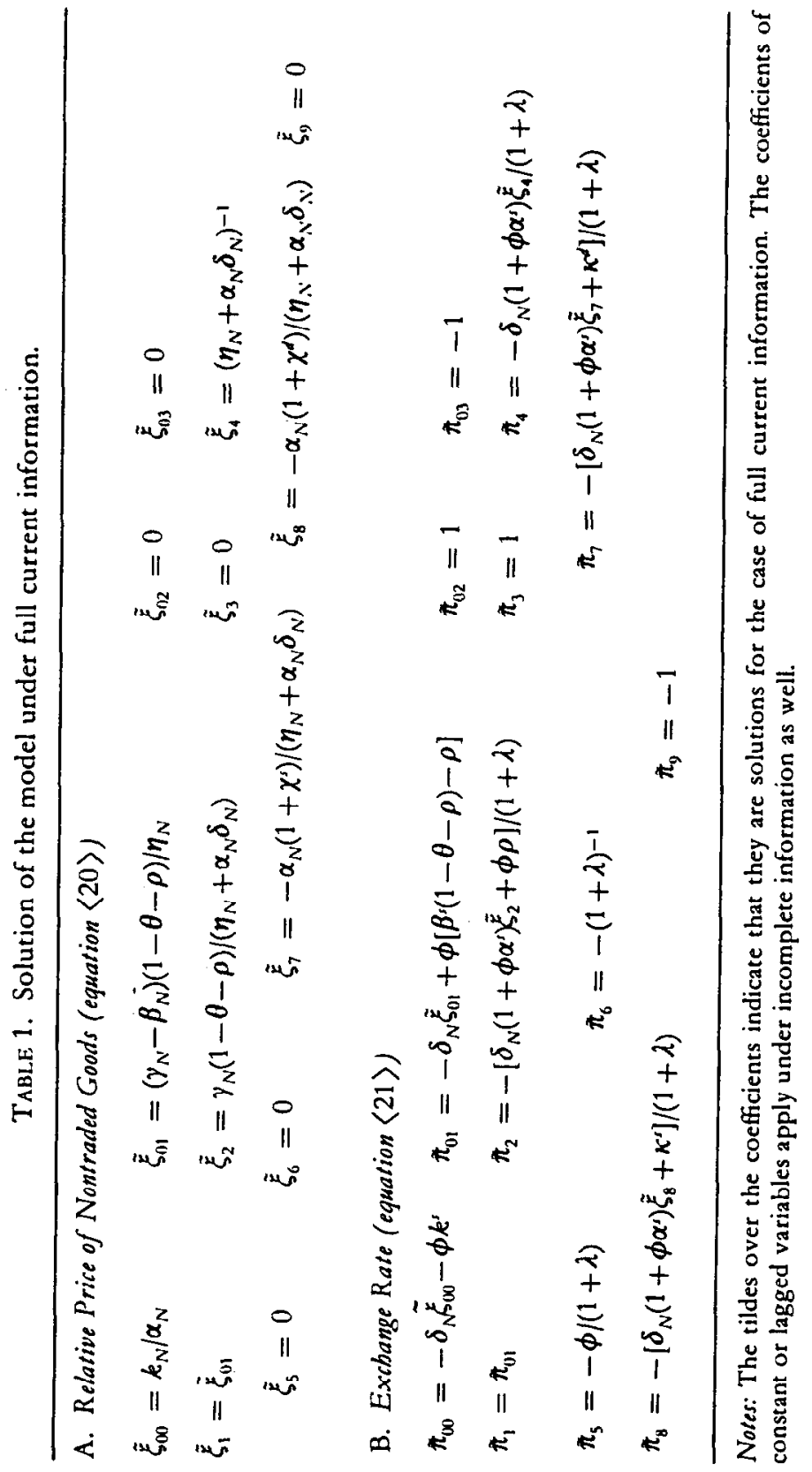


price of nontraded goods has a larger impact on excess demand than does a permanent change in relative prices. The reason for this is that transitory changes in relative prices alter the perceived real interest rate in the home country, and thus generate intertemporal substitution effects, whereas permanent changes in relative prices do not. To see why this is the case, note from $\langle 6\rangle-\langle 9\rangle$ that the domestic real interest rate can be written as

$$
r_{t}=r_{t}^{*}-\delta_{\lambda}\left(E p_{n t+1}-p_{n t}\right)
$$

where $r_{t}^{*}=i_{t}^{*}-\left(E P_{t+1}^{*}-P_{T t}^{*}\right)$. That is, as in Dornbusch (1983), an expected fall, for instance, in the relative price of nontraded goods raises the domestic real interest rate relative to the given world real interest rate, $r_{t}^{*}$. Therefore, a transitory increase in today's relative price of nontraded goods induces intertemporal substitution effects (captured by $\alpha_{N} \delta_{N}$ ) that reinforce the direct effects of the change in relative prices on excess demand (captured by $\eta_{N}$ ). These intertemporal substitution effects do not arise in response to permanent changes in relative prices.

The remaining preliminary issue concerns the coefficient $1-\theta-\rho$ that is associated with the government purchase variables in equations $\langle 24\rangle$ and $\langle 25\rangle$. As can be seen from equations $\langle 1\rangle-\langle 4\rangle$, the coefficient $1-\theta-\rho$ captures the effects of government purchases on private sector wealth (or permanent income). It is assumed throughout the analysis that $1-\theta-\rho \geqslant 0$, which implies that a permanent increase in government purchases reduces private sector real wealth. The reasoning is the same as in Barro (1981, p. 1092, esp. ftn. 9): Government purchases are treated as a composite commodity (a bundle of $\gamma_{N}$ nontraded goods and $\gamma_{T}=1-\gamma_{N}$ traded goods) that provide public services that both substitute for private consumption and provide inputs into the production process. It is unlikely that government purchases of a particular type will provide services that are strongly characterized by both of these attributes. Therefore, since $\theta$ and $\rho$ are both less than or equal to one, it is reasonable to assume that the composite services provided by government purchases are such that $1-\theta-\rho \geqslant 0$.

Before moving on to look at the effects of government purchases, it should be noted from Table 1 that the coefficients of the other variables have the expected signs and magnitudes. Most notably, under full current information money supply and demand shocks have no real effects, domestic money supply increases lead to an equiproportionate depreciation of the domestic currency, and foreign money supply increases lead to an equiproportionate appreciation of the domestic currency.

The stage is now set to examine the effects of government purchases on the real exchange rate, movements of which are opposite those of the relative price of nontraded goods, and the nominal exchange rate. Consider first the effects of a transitory increase in government purchases. From Panel A of Table 1 it can be seen that this will result in an increase in the relative price of nontraded goods (i.e., an appreciation of the real exchange rate), since increases in government purchases create an excess demand for nontraded goods (at initial relative prices and real wealth). In addition, from Panel $B$ it can be seen that the home currency is also likely to appreciate. This arises for three reasons. First, the increase in government purchases raises real output, $y_{t}$, since it temporarily raises the relative price of nontraded goods and the real interest rate (see equation $\langle 26\rangle$ ). The term 
$\delta_{N} \phi \alpha_{s} \tilde{\xi}_{2}$ in the numerator of $\pi_{2}$ captures this. Second, the rise in the relative price of nontraded goods tends to raise the domestic price level, and money market equilibrium requires that the home currency appreciate to offset this as reflected by the term $\delta_{N}, \bar{\zeta}_{2}$. Third, as long as government purchases enhance private productivity, the demand for real balances is directly increased, and the home currency must appreciate to maintain money market equilibrium (the term $\phi \rho$ captures this).

Turning to the impact of a permanent increase in government purchases, the accompanying change in the relative price of nontraded goods is ambiguous. The reason for this is that in addition to the direct effects, which tend to create an excess demand for nontraded goods, permanent increases in government purchases also reduce private sector wealth and this tends to create an excess supply of nontraded goods. Thus if wealth effects are strong enough, a permanent increase in government purchases could result in a fall in the relative price of nontraded goods. In light of this ambiguity, it is not surprising that the domestic currency may appreciate or depreciate in response to a permanent increase in government purchases.

It is also of some interest to compare the effects of permanent and transitory changes in government purchases on relative prices. Holding relative prices constant, the excess demand generated by a transitory increase in government purchases exceeds that generated by a permanent increase because of the reduction in private sector wealth associated with the latter. However, a transitory increase in government purchases only temporarily raises the relative price of nontraded goods, and thus equilibrium is restored not only through intratemporal substitution effects, but also through the intertemporal substitution effects resulting from the rise in real interest rates. As a result, the relative price of nontraded goods may rise more or less in response to a transitory increase in government purchases than in response to a permanent increase in government purchases. ${ }^{17}$ However, it seems reasonable to suppose that the relative price of nontraded goods will rise more, and hence the real exchange rate will appreciate more, in response to a transitory increase in government purchases than in response to a permanent increase. This will be the case if (a) the wealth effects accompanying permanent changes in government purchases are fairly strong (in which case $p_{n t}$ might fall when $e_{t}^{P}$ rises) and/or (b) the excess demand elasticity for nontraded goods with respect to future relative price changes, $\alpha_{N} \delta_{N}$, is small. The latter condition is more likely the more open the economy (and hence the smaller the share of nontradeables, $\delta_{N}$ ), the more rapidly the marginal product of labor diminishes in the nontraded goods sector (in which case intertemporal reallocations of labor effort mostly affect the production of traded goods), and the weaker intertemporal substitution effects are. ${ }^{18}$

\section{Implications for other Real Variables}

Table 2 shows the effects of changes in government purchases on nontraded goods production, real output, and the current account. As can be seen, the output of nontraded goods is increased by a transitory rise in government purchases since they raise the current period relative price of nontraded goods and the perceived real interest rate. ${ }^{19}$ However, permanent increases in 


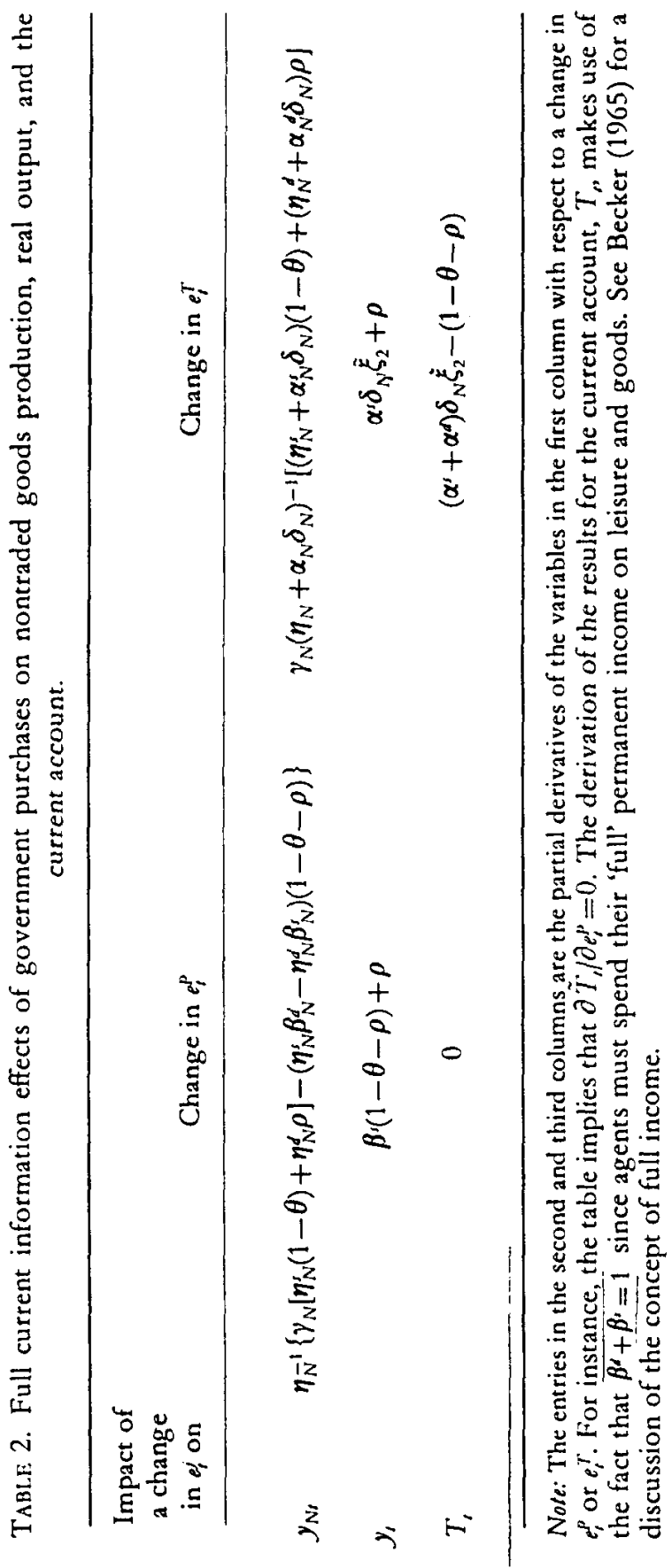


government purchases may be associated with either a rise or a fall in the output of nontraded goods. In contrast, real output, including both traded and nontraded goods, expands in response to increases in both permanent and transitory government purchases, although the mechanism differs in the two cases. In the case of a permanent increase in government purchases, real output expands as a consequence of the fact that private sector wealth falls and, with leisure being a normal good, the supply of labor rises. On the other hand, real output is raised by a transitory increase in government purchases mainly as a result of intertemporal substitution effects: A transitory increase in government purchases raises the perceived real rate of return and leads agents to substitute future for current leisure. The expansion in current period labor supply results in a rise in real output.

Finally, Table 2 also shows the current account effects of changes in government purchases. As can be seen, permanent changes in government purchases do not influence the current account. This is an open economy extension of Barro's (1981) results which showed that permanent changes in government purchases do not generate an excess supply of or demand for goods at a constant real interest rate. As can be seen from equation $\langle 26\rangle$, in the present setup the domestic real interest rate is not affected by permanent changes in government purchases (since $\Delta p_{n t}=\Delta\left(E p_{n t+1}\right)$ ), and hence Barro's results imply that permanent changes in government purchases do not alter the current account in as much as it reflects the balance between income and expenditure (i.e., between the supply and demand for goods). In the case of a transitory increase in government purchases the current account may, generally speaking, move in either direction. On the one hand, as can be seen from Table 2, a transitory increase in government purchases directly worsens the current account since it raises expenditure relative to income by the amount $1-\theta-\rho$. On the other hand, a transitory increase in government purchases raises the real interest rate and leads to an intertemporal reallocation of expenditure and labor supply that works to improve the current account as shown by the term $\left(\alpha^{s}+\alpha^{d}\right) \delta_{N} \xi_{2}$. To gain further insight into this result note that

$$
\left(\alpha^{s}+\alpha^{\alpha}\right) \delta_{N} \tilde{\xi}_{2}-(1-\theta-\rho)=\frac{-(1-\theta-\rho)}{\eta_{N}+\alpha_{N} \delta_{N}}\left[\eta_{N}+\delta_{N} \gamma_{T} \alpha_{T}\left(\frac{\dot{\alpha}_{N}}{\alpha_{T}}-\frac{\gamma_{N}}{\gamma_{T}}\right)\right],
$$

where use has been made of the fact that by definition $\alpha^{s}+\alpha^{d}=\alpha_{N}^{s}+\alpha_{T}^{s}+\alpha_{N}^{d}+\alpha_{T}^{d}=\alpha_{N}+\alpha_{T}$

. Therefore, the current account must deteriorate in response to a transitory increase in government purchases if the relative responsiveness of the excess demand for nontraded goods to intertemporal relative price movements exceeds the relative share of government purchases directed towards nontraded goods. Even if this transfer-like condition is not satisfied the current account may nonetheless deteriorate. The most likely outcome thus seems to be that the current account will worsen in response to a transitory increase in government purchases.

\section{Composition Changes}

Besides changing the level of government purchases the fiscal authorities may also influence domestic economic activity and resource allocation by altering the 
composition of government purchases as captured by the policy parameter $\gamma_{\mathrm{N}}$ As can be seen from Table 1, an increase in the share of government purchases falling on nontraded goods will lead to an appreciation of both real and nominal exchange rates given that transitory government purchases and innovations in permanent government purchases are at normal levels (i.e., zero). From Table 2 it can also be seen that increasing the share of government purchases falling on nontraded goods will raise the output of nontraded goods while leaving the overall level of real output, $y_{t}$, unchanged (to see this note that the $e_{t}^{p}$ coefficients in Table 2 are also the reduced form $G_{t-1}^{P}$ coefficients). That is, shifts in the composition of government purchases affect the composition of output but not its overall level. This result reflects the fact that changes in the composition of government purchases are, in essence, being treated as permanent here (since the $\xi$ 's and $\pi$ 's are taken to be constant across periods), and hence they influence intratemporal rather than intertemporal relative prices. As a consequence, changes in the composition of government purchases also turn out not to influence the current account in the present setup. Extending the model to look at transitory changes in the composition of government purchases is beyond the scope of this paper but would be a fruitful exercise.

\section{Government Purchases under Incomplete Information}

If agents are not fully informed about the state of the economy they must use the information they can glean from market prices and other sources to make inferences about current and future economic conditions. In this section it is assumed that the information agents have at their disposal consists of a knowledge of the structure and past history of the economy, the six market prices they observe $\left(P_{T t}, P_{T}^{*}, i_{t}, i_{t}^{*}, P_{N t}\right.$, and $\left.S_{t}\right)$, and knowledge of the current level of government purchases, $G_{0}{ }^{20}$ From the arbitrage conditions $\langle 8\rangle$ and $\langle 9\rangle$ it can be seen that only four of the market prices agents observe convey useful information. For ease of exposition, it is therefore assumed that agents ise the information conveyed by $P_{T t}^{*}, i_{t}^{*}, P_{N t}$, and $S_{t}$ in forming their expectations. Also, since in most countries debates over government spending and the mechanisms that trigger automatic changes in such spending are a matter of public record, it seems reasonable to assume that agents know the actual level of government purchases but not its breakdown into permanent and transitory components. This assumption has the virtue of introducing uncertainty about the composition of government purchases without introducing the added complication that agents confuse fiscal shocks with monetary shocks or other changes in their economic environment.

Formally, the information agents have about current market conditions consists of the following: Equations $\langle 10\rangle$ and $\langle 11\rangle$ imply that since agents observe $P_{T t}^{*}$ and $i_{t}^{*}$ they know the linear combinations

$$
\begin{gathered}
g_{T t}^{*}=m_{t}^{*}+\chi^{d} u_{t}^{j^{*}}+\chi^{s} u_{t}^{*} \\
g_{i t}^{*}=u_{t}^{d^{*}}+u_{t}^{*} .
\end{gathered}
$$

Since agents know the current level of government purchases, equations $\langle 14\rangle$ and $\langle 15\rangle$ imply that agents know the current innovation in government purchascs, 


$$
g_{t}=e_{t}^{p}+e_{t}^{T},
$$

but not its breakdown into permanent and transitory components. The information conveyed by $P_{N_{t}}$ and $S_{t}$ can be seen by combining equations $\langle 24\rangle$ and $\langle 25\rangle$ with the other information at agents' disposal, which includes knowledge of their own expectations, to obtain

$$
\begin{gathered}
g_{N t}=\beta_{N} m_{t}+u_{N t} \\
g_{s t}=(1+\phi \beta s) m_{t}-\phi u_{t}-v_{t} .
\end{gathered}
$$

The convenient feature of the information set $\langle 27\rangle-\langle 31\rangle$ is that the effects of government purchase shocks $\left(e_{t}^{\mathrm{p}}\right.$ and $\left.e_{t}^{\top}\right)$, other domestic shocks $\left(m_{t}, u_{N t}, w_{t}^{s}\right.$, and $\left.v_{t}\right)$, and foreign shocks $\left(m_{t}^{*}, u_{t}^{*}\right.$, and $\left.u_{t}^{*}\right)$ are not confounded with one another. Therefore these three groups of shocks can be examined independently. In the next subsection the effects of government purchases are discussed in light of the information structure just outlined. Part B of this section contains some brief remarks concerning alternative information structures. ${ }^{21}$

\section{A. Effects of Government Purchases}

As before, equations $\langle 20\rangle-\langle 25\rangle$ can be solved using the method of undetermined coefficients in order to ascertain the relative price and exchange rate effects of government purchases. However, since agents have incomplete information, $E e_{t}^{\mathrm{P}}=e_{t}^{\mathrm{P}}$ no longer holds as in Section II. Instead, agents use the information set $\langle 27\rangle-\langle 31\rangle$ to form an optimal forecast of the current innovation in government purchases. It can be shown that this forecast is given by

$$
E e_{t}^{p}=b\left(e_{t}^{p}+e_{t}^{T}\right) ; b=\sigma_{P}^{2} /\left(\sigma_{P}^{2}+\sigma_{T}^{2}\right) \text {. }
$$

That is, agents observe the current innovation in government purchases, $g_{t}=e_{t}^{p}+e_{t}^{T}$, and their best 'guess' is that the fraction $b$, which equals the portion of the total variance of government purchases accounted for by the permanent component, represents a permanent change in government purchases.

Having solved for agent's expectations, straightforward application of the method of undetermined coefficients yields

$$
\xi_{1}=\xi_{2}=b \tilde{\xi}_{1}+(1-b) \tilde{\xi}_{2} .
$$

That is, under incomplete information, the relative price of nontraded goods, or real exchange rate, responds in the exact same manner to both permanent and transitory changes in government purchases. This occurs because agents are unable to distinguish effectively between the two. In addition, the incomplete information response of the relative price of nontraded goods to changes in government purchases is simply a weighted average of its full current information responses to permanent and transitory changes in government purchases, the weights being the fraction of the total variance of government purchases accounted for by permanent and transitory changes.

This last result has two important implications for the allocation of resources under incomplete information relative to the full current information benchmark. ${ }^{22}$ First, the relative price of nontraded goods will 'overrespond' to permanent changes in government purchases under incomplete information $n^{23}$ since agents will underestimate the true wealth effects associated with such 
changes by incorrectly attributing part of the total innovation in government purchases to be due to a transitory change in government purchases. It follows that in response to a permanent increase in government purchases, for example, agents will allocate too much of their current period labor supply to the production of nontraded goods and too little of their current period expenditure to purchasing them. In addition, since the perceived real interest rate rises, agents will mistakenly reallocate resources intertemporally in response to a permanent increase in government purchases. As a result, too much labor and too little expenditure will be allocated to the current period. The second implication of equation $\langle 32\rangle$ for resource allocation under incomplete information is that the relative price of nontraded goods will 'underrespond' to transitory changes in government purchases since agents will overestimate their wealth effects. This has implications for the allocation of resources within and across periods that are just the reverse of those associated with permanent changes in government purchases. ${ }^{24}$

In addition, it can be shown that results similar to equation $\langle 32\rangle$ hold for other variables as well. For instance, it can be shown that

$$
\begin{gathered}
\pi_{1}=\pi_{2}=b \tilde{\pi}_{1}+(1-b) \pi_{2} \\
\partial T_{t} / \partial e_{t}^{P}=\partial T_{t} / \partial e_{t}^{T}=b\left(\partial \tilde{T}_{t} / \partial e_{t}^{P}\right)+(1-b)\left(\partial \tilde{T}_{t} / \partial e_{t}^{T}\right),
\end{gathered}
$$

where $\left(\partial \tilde{T}_{t} / \partial e^{\prime}\right)$ for $j=P, T$ are given by the entries in Table 2 . Results similar to equation $\langle 33\rangle$ also hold for the production of nontraded goods and for real output. Note that equation $\langle 33\rangle$ implies that under incomplete information on government purchases, both permanent and transitory increases in government purchases will lead to a deterioration of the current account-the current account thus overresponds to permanent changes in government purchases and underresponds to transitory changes.

\section{B. Alternative Information Structures}

The preceding results were based on the assumption that the information structure is characterized by equations $\langle 27\rangle-\langle 31\rangle$. As already noted, this information structure is convenient because it allows the various shocks to be broken into three independent groups: government purchase shocks, other domestic shocks, and foreign shocks. The effects of the shocks in each of these three groups can then be analyzed separately since they are not confounded by imperfectly informed agents. This section considers the implications of alternative information structures.

The easiest generalization is to assume agents do not know the current level of government purchases. In this case, the information at agents' disposal consists only of market prices. The information set can thus be given by $\langle 27\rangle,\langle 28\rangle$,

and

$$
g_{N t}=\beta_{N} m_{t}+u_{N t}+\gamma_{N}(1-\theta-\rho)\left(e_{t}^{p}+e_{t}^{T}\right),
$$

$$
g_{S t}=\left(1+\phi \beta^{s}\right) m_{t}-\phi u_{t}-v_{t}-\phi \rho\left(e_{t}^{p}+e_{t}^{T}\right) .
$$

It is easily seen from the expressions for the information content of the price of nontraded goods and the exchange rate, $g_{N t}$ and $g_{S t}$, that these two prices now convey information about government purchases as well as about other domestic 
shocks. As a consequence, there will be a confusion between monetary and fiscal policy shocks that was not present in the analysis of Section III.A. Agents will continue to respond to permanent and transitory changes in government purchases in a similar manner since they still cannot be distinguished from one another. However, the magnitude of these responses will differ from those just outlined because government purchases will, as a result of information confounding, bear some resemblance to the effects of monetary policy and other shocks that they previously did not.

It should be noted that while domestic monetary and fiscal shocks will be confused when agents do not know the current level of government purchases, the separation between domestic and foreign shocks will continue to hold. This feature will characterize any model in which the foreign variables that agents observe, $P_{T t}^{*}$ and $i_{t}^{*}$ in this setup, are economy-wide variables observed by all agents. For instance, the existence of local markets for nontraded goods and economy-wide markets for traded goods will not destroy agents' ability to separate foreign from domestic shocks. In order to extend the model to allow for a confusion between domestic and foreign shocks there must be some foreign variables that are not observed economy-wide as in Kimbrough (1983b, 1984). ${ }^{25}$

\section{Conclusion}

The preceding sections of the paper have examined the effects of government purchases in an open economy. In as much as Barro (1981) has analyzed the effects of government purchases in a closed economy setting, the paper's main contribution is to draw out the implications of changes in government purchases for variables such as the real exchange rate and the current account that can only be studied in an open economy framework. The paper's results concerning these open economy variables can be summed up as follows: As in Barro's work a sharp distinction is drawn between the effects of permanent and transitory government purchases. Under full current information about the level and composition of government purchases, a transitory increase in government purchases will lead to an appreciation of the real exchange rate (i.e., a rise in the relative price of nontraded goods) and a probable worsening of the current account, while a permanent increase in government purchases has an ambiguous impact on the real exchange rate and will not influence the current account. In addition, under fairly reasonable conditions the real exchange rate will appreciate more in response to a transitory rise in government purchases than in response to a permanent rise. Alternatively, if agents have incomplete information about the composition of government purchases, permanent and transitory changes in government purchases will have identical effects on the real exchange rate and the current account.

An interesting area for future research would be to implement the model empirically. One key aspect of such a study would be to devise an econometric procedure for dividing government purchases into permanent and transitory components. Possible approaches include the method used by Barro (1981) that focuses on the transitory nature of wartime defense spending, the method used by Friedman (1957) in his study of the consumption function, and the time series approach of Beveridge and Nelson (1981). Recently, Ahmed (1983) and Azam 
(1983) have undertaken studies along these lines. Using annual data for the United Kingdom from 1908-80 and quarterly data for Canada covering the period 1963-80 they obtain results for the current account that are consistent with the equilibrium approach adopted here. Further work along such lines should prove useful.

Returning to the theory, an interesting extension that is beyond the scope of this paper is the possible use of government purchases as a tool of stabilization policy. In order to address this problem, the government purchase rules $\langle 15\rangle$ and 〈16) could be modified to incorporate feedback on past shocks as well as a response to contemporaneously observed variables. The model could then be used to discuss such issues as the optimal government purchase rule. The results on resource allocation under incomplete information presented in Section III.A highlight one crucial property that the optimal government purchase rule would possess: the fiscal authorities should announce both the level and the composition of government purchases or, equivalently, rules for determining the level and composition of government purchases should be clearly spelled out and then adhered to. ${ }^{26}$ In this way agents would be fully informed about government purchases and the resources at hand could be allocated in the most efficient manner.

\section{Appendix}

The supply and demand functions $\langle 1\rangle-\langle 4\rangle$ are central to the discussion of government purchases that is presented in the main body of this paper. They are written in a manner that emphasizes the distinct roles played by the intratemporal substitution effects triggered by changes in the relative price of nontraded goods, $p_{n t}$, and the intertemporal substitution effects triggered by changes in the real interest rate, $r_{t}$. However, given that there are two goods and two periods $(t$ and $t+1)$ that explicitly enter the supply and demand functions, there are three, not two, relative prices. This appendix shows how the supply and demand functions can be rewritten to demonstrate that there are in fact three relative prices in the model. This helps to highlight the restrictions on supply and demand elasticities that are implicit in the assumption that preferences are such that $\langle 1\rangle-\langle 4\rangle$ hold.

Using equations $\langle 6\rangle,\langle 7\rangle$, and the fact that $p_{n t}=P_{N t}-P_{T t}$ it can be shown with a litele manipulation that the supply and demand functions $\langle 1\rangle$ and $\langle 2\rangle$ can be rewritten as

$$
\begin{gathered}
y_{N t}=\ldots+\left(\eta_{N}+\alpha_{N}^{5} \delta_{N}\right)\left(P_{N t}-P_{T t}\right)-\alpha_{N}^{s}\left(1-\delta_{N}\right)\left(E P_{T_{t+1}}-P_{T_{t}}-i_{t}\right) \\
-\alpha_{N} \delta_{N}\left(E P_{N t+1}-P_{T t}-i_{t}\right) \\
c_{N t}=\ldots-\left(\eta_{N}^{d}+\alpha_{N}^{d} \delta_{N}\right)\left(P_{N t}-P_{T t}\right)+\alpha_{N}^{d}\left(1-\delta_{N}\right)\left(E P_{T t+1}-P_{T t}-i_{t}\right) \\
+\alpha_{N}^{d} \delta_{N}\left(E P_{N t+1}-P_{T t}-i_{t}\right),
\end{gathered}
$$

where ... captures the non-relative price factors that influence supply and demand. As can be seen from equations $\langle A 1\rangle$ and $\langle A 2\rangle$, the supply and demand functions $\langle 1\rangle$ and $\langle 2\rangle$ do indeed allow for three relative prices to influence supply and demand. These relative prices are the relative price of nontraded goods today in terms of traded goods today $\left(P_{N}-P_{T t}\right)$, the relative price of traded goods tomorrow in terms of traded goods today $\left(E P_{T_{t}}-P_{T_{t}}-i_{t}\right)$, and the relative price of nontraded goods tomorrow in terms of traded goods today $\left(E P_{N i+1}-P_{T t}-i_{t}\right)$. As can be seen from equations $\langle A 1\rangle$ and $\langle A 2\rangle$, one assumption implicit in the supply and demand functions of the text is that goods are gross substitutes. Another, and one that is not so apparent from $\langle A 1\rangle$ and $\langle A 2\rangle$ but that is discussed in Section II.B of the text, is that transitory changes in within-period relative 
prices (i.e., of $p_{n t}$ ) have stronger effects on supply and demand than do permanent changes. Other implications of a more technical nature can be seen from $\langle A 1\rangle$ and $\langle A 2\rangle$. Similar remarks also apply to the real outpur and consumption function given by equations $\langle 3\rangle$ and $\langle 4\rangle$. As noted in the text, they explicitly embody the assumption that changes in within-period relative prices do not affect agents decisions regarding the intertemporal allocation of resources except to the extent that they are transitory and thus alter intertemporal relative prices.

\section{Notes}

1. Most of the work that has been done on the subject, such as Boyer and Hodrick (1982) and Marion (1982), has tended to focus by and large on the (nominal) exchange rate effects of fiscal policy. For a recent exception using an intertemporal utility maximization setup see Greenwood (1983). He looks at the effects of changes in government spending on the trade balance, the balance of payments, and relative prices.

2. The paper does not consider the use of the inflation tax to finance government purchases. See Gilles and I.awrence (1981) and Aiyagari and Gertler (1983) for discussions of the inflation tax as a means of government finance. The paper also does not consider non-lump sum taxes. See Barro (1981) on this subject.

3. Therefore, $\theta-\theta_{\alpha}$ measures the degree to which government purchases substitute for private consumption of traded goods.

4. It is shown in the appendix that the supply and demand functions $\langle 1\rangle-\langle 4\rangle$ can be written in terms of the three relative prices that are implicit in the model: $P_{t_{t}}-P_{T_{i}}, E P_{T_{i+1}}-P_{T_{t}}-i_{t}$, and $E P_{x+1}-P_{r t}-i$. That the supply and demand functions can be written in this manner helps to bring out the restrictions on price elasticities involved in specifying preferences in the manner outlined above. See Phlips (1974) and Deaton and Muellbauer (1980) for discussions of the properties of separable urility functions.

5. It is assumed here that the home country is neither a net creditor nor debtor on world capital markets in the initial period. The ability to borrow or lend in a world capital marker does not alter the country's real wealth but it does allow an optimal allocation of spending across periods.

6. Recall that $\theta$ and $\rho$ capture the consumption substitution and productivity effects of government purchases relating to hoth traded and nontraded goods.

7. This is strictly true only in the neighborhood of current account balance where the share of expenditure falling on nontraded goods just matches the share of output accounted for by nontraded goods. Proof is available upon request.

8. Notice that since both $M_{t}^{d}$ and $P$, are in logarithms the demand for money function $\langle j\rangle$ does have an elasticity of one with respect to changes in the price level.

9. These equations are derived under the assumption of full current information in the toreign country. The parameters $\chi^{d}$ and $\chi^{\prime}$ are conglomerations of the substitution and wealth elasticities that characterize the world economy and may be positive or negative; no results regarding government purchases depend on their signs.

10. No feedback elements are incorporated in the money supply rule $\langle 10\rangle$ because in the present setup real variables are not influenced by systematic monetary policy. This need not be the case if differential information is introduced into the model as in Kimbrough (1984). For a discussion of the importance of the behavior of forward rates for the role of monetary policy in a differential information, open economy setup see Kimbrough (1983c).

11. In order for transitory changes in government purchases to leave the present value of government purchases (and taxes) unaffected, they must be accompanied by an adjustment of all future levels of permanent government purchases. That is, future values of $e_{t}^{p}$ should depend in a known way on $e_{1}^{T}$. However, if transitory changes in government spending are small relative to the present value of all future government purchases, and if the adjustment is spread over all future periods, this effect will be small. This assumption is implicit in equations $\langle 14\rangle$ and $\langle 15\rangle$.

12. All prices are assumed to be unity in the initial equilibrium so that there is no units problem in equation $\langle 16\rangle$. 
13. Equation $\langle 19\rangle$ is more properly interpreted as a definition of the trade balance since the definition of income, $y_{i}$, implicitly ignores net interest earnings by domestic residents on their foreign assets so that the service account is omitted from $\langle 19\rangle$. In the initial period, where the country is taken to be neither a net creditor nor debtor in the world capital market, this omission is irrelevant but it may be significant in later periods and in applied work.

14. It also turns out that, partially as a result of the assumed information structure, when agents have incomplete information the effects of government purchases are related in a very useful manner to their effects under full current information.

15. In conjunction with equations $\langle 9\rangle$ and $\langle 11\rangle$, the exchange rate solution implies a solution for $P_{\mathrm{r}_{s}}$ which, in conjunction with the definition of $p_{n}$, implies a solution for $P_{\mathrm{N}, t}$. These solutions, along with equations $\langle\sigma\rangle-\langle 8\rangle$ and $\langle 10\rangle$, implicitly solve for the real interest rate, $r_{\text {. }}$.

16. The derivation of equation $\langle 24\rangle$ makes use of equations $\langle 1\rangle,\langle 2\rangle,\langle 6\rangle-\langle 11\rangle$, and $\langle 14\rangle-\langle 19\rangle$. The derivation of equation $\langle 25\rangle$ makes use of equations $\langle 3\rangle,\langle 18\rangle$, and $\langle 5\rangle-\langle 16\rangle$ as well as the definition of $p_{n}$.

17. Formally, it can be shown that

$$
\tilde{\xi}_{2}-\tilde{\xi}_{1}=\eta_{i}^{-1}\left\{\left[-x_{v} \delta_{v} \gamma_{v}(1-\theta-\rho) /\left(\eta_{v}+x_{s} \delta_{v}\right)\right]+\beta_{s}(1-\theta-\rho)\right\} .
$$

18. The latter two factors will be reflected in the magnitude of $x_{\uparrow}$.

19. Throughout this section it is assumed that government purchases do not have a strong negative impact on private sector production opportunities.

20. Agents are more likely to know nominal rather than real government purchases. However, this distinction is irrelevant here since knowledge of $P_{W}, P_{r}$ and equation $\langle 7\rangle$ allows agents to compute the current price level.

21. The incomplete information effects of the model's other shocks are not discussed in order to keep the paper to a reasonable length. Results for these shocks are available upon request.

22. It should be pointed out that the remarks that follow are not meant to imply that there is rampant market failure (since there is not) but are intended to highlight the implications of incomplete information for resource allocation.

23. Recall that in Section II.B $\tilde{\xi}_{2}-\tilde{\xi}_{1} \geqslant 0$ was shown to hold under reasonable conditions.

24. For instance, in response to a transitory increase in government purchases too little labor will be allocated to the current period.

25. In addition, as shown by Kimbrough (1983c), there must also be no prices, such as the forward exchange rate with a time invariant risk premium, that allow agents to separate local from aggregate information, or else agents can deduce the economy-wide average values of the foreign variables they observe.

26. This is essentially one of the cornerstones of Friedman's (1948) policy prescription for economic stability. In light of recent thinking, it brings to mind the interesting and important issue of time consistency. This issue has recently been addressed by Lucas and Stokey (1983) in regard to the government's financing decisions, but not its spending decisions as suggested here. This would be an interesting area for future research.

\section{References}

Aнмер, S., 'Temporary and Permanent Government Spending in an Open Economy: Some Evidence from the UK', unpublished manuscript, University of Rochester, 1983.

Aiyagari, R. Aid M. Gertier, 'Debt Management in Ricardian and Non-Ricardian Regimes', unpublished manuscript, University of Wisconsin, 1983.

Azam, A.H.M.G., 'Some Empirical Results on the Current Account: The Permanent Income Hypothesis and Government Fiscal Policy', unpublished manuscript, Duke University, 1983.

Balley, M.J., National Income and the Price Level: A Study in Macroeconomic Theory, 2nd ed., New York: McGraw-Hill, 1971.

Barro, R.J., 'Are Government Bonds Net Wealth?', Journal of Political Economy, November/December 1974, 82: 1095-1117.

Barro, R.J., 'A Capital Markei in an Equilibrium Business Cycle Model', Econometrica, September 1980, 48: 1393-1417.

Barro, R.J., 'Output Effects of Government Purchases', Journal of Political Economy, December 1981, 89: 1086-1121. 
Becker, G.S., 'A Theory of the Allocation of Time', Economic Journal, Seprember 1965, 75: 493-517.

Beveridge, S. AND C.R. Nelson, 'A New Approach to Decomposition of Economic Time Series into Permanent and Transitory Components with Particular Attention to Measurement of the Business Cycle', Journal of Monetary Economics, March 1981, 7: 151-174.

Bhandarl, J.S., 'Informational Efficiency and the Open Economy', Journal of Money, Credit and Banking, November 1982, 14: 457-478. (1982a)

Bhandarl, J.S., 'Staggered Wage Setting and Exchange Rate Policy in an Economy with Capital Assets', Journal of International Money and Finance, December 1982, 1: 275-292. (1982b)

Boyer, R.S. AND R.J. HODRICK, 'Perfect Foresight, Financial Policies, and Exchange-Rate Dynamics', Canadian Journal of Economics, February 1982, 15: 143-164.

Deaton, A. AND J. Muelladier, Economics and Consumer Behavior, Cambridge: Cambridge University Press, 1980.

Dorneuscr, R., 'Expectations and Exchange Rate Dynamics', Journal of Political Economy, December 1976, 84: 1161-1170.

DornbusCH, R., 'Real Interest Rates, Home Goods, and Optimal External Borrowing', Journal of Political Economy, February 1983, 91:141-153.

Flood, R.P. ANd NanCY Peregrim Marion, 'The Transmission of Disturbances under Alternative Exchange Rate Regimes with Optimal Indexing', Quarterly Journal of Economics, February 1982, 96: $43-66$.

Friedmas, M., 'A Monetary and Fiscal Framework for Economic Stability', American Economic Review, June 1948, 38: 245-264.

Friedman, M., A Theory of the Consumption Function, Princeton: Princeton University Press, 1957.

Gilles, C. AND C. Lawrence, 'A Strong Ricardian Proposition: The Equivalence of Taxes, Bonds, and Money in Financing Public-Sector Activity', unpublished manuscript, Columbia University, 1981.

Greenwood, J., 'Nontraded Goods, the Trade Balance, and the Balance of Payments', Working Paper No. 8417C, University of Western Ontario, 1983. Forthcoming, Canadian Journal of Economics.

Helpmax, E., 'An Exploration in the Theory of Exchange-Rate Regimes', Journal of Political Economy, October 1981, 89: 865-890.

Kimbrough, K.P., 'Price, Output, and Exchange Rate Movements in the Open Economy', Journal of Monetary Economics, January 1983, 11: 25-44. (1983a)

Kimbrough, K.P., 'Exchange Rate Policy and Monetary Information', Journal of International Money and Finance, December 1983, 2: 333-346. (1983b)

Kimbrough, K.P., 'The Forward Rate as a Predictor of the Future Spot Rate, the Role of Policy, and Exchange Rate Regime Choice', unpublished manuscript, Duke University, 1983. Forthcoming, International Economic Review. (1983c)

KImbrough, K.P., 'Aggregate Information and the Role of Monetary Policy in an Open Economy', Journal of Political Economy, April 1984, 92: 208-285.

LuCAS, R.E. AND L.A. RAPpisc, 'Real Wages, Employment, and Inflation', Journal of Poliaical Economy, September/October 1969, 77: 721-754.

Lucas, R.E. and Nancy L. Stokey, 'Optimal Fiscal and Monetary Policy in an Economy without Capital', Journal of Monetary Economics, July 1983, 12: 55-93.

Marion, Nancy Peregrim, 'The Exchange-Rate Effects of Real Disturbances with Rational Expectations and Variable Terms of Trade', Canadian Journal of Economics, February 1982, 15: $104-118$.

Phups, L., Applied Consumption Analysis, Amsterdam: North-Holland, 1974.

SAIDI, N.H., 'Expectations, International Business Cycles, and the Balance of Payments', Journal of Money, Credit and Banking, August 1982, 14: 327-346.

Stockmax, A.C., 'A Theory of Exchange Rate Determination', Journal of Political Economy, August 1980, 88: 673-698.

Stockman, A.C., 'Real Exchange Rates under Alternative Nominal Exchange-Rate Systems', Journal of International Money and Finance, August 1983, 2: 147-166.

Turnovsky, S.J., 'Monetary Policy and Foreign Price Disturbances Under Flexible Exchange Rates: A Stochastic Approach, Journal of Money, Credit, and Banking, May 1981, 13: 156-176. 